female, roll her like a ball upon the ground for a distance of several metres, and continue this conduct, without rest or relaxation, for two days, until the poor female, who had not been able to recover her equilibrium for a moment, had at last evacuated all her ova.

Being then obliged to suspend my observations, I returned a fortnight afterwards, and, carefully examining the surface and the edges of the basin, I had the satisfaction of discovering several little embryos, which swam with considerable difficulty, and which a more careful examination enabled me to recognize as the young: fry of the telescope-fish.

They had the same double caudal fin, and the same sinuosity of the upper part of the back; but the eyes were not yet very prominent.

Having brought them to Paris and observed them carefully, they furnished me with the following results. At its earliest age the telescope-fish has the elongated form of most of our young fishes ; the transparency of the body allows us to distinguish plainly the air-bladder, lodged in the upper part of the body, and the intestine, forming a right angle, of which the apex is opposite to the bladder. So long as the embryo lives at the expense of the umbilical vesicle, it swims easily and in a horizontal position; but subsequently the absorption of exterior aliment has for its result an abnormal and irregular development, which, in nearly half the specimens, causes a deviation from the normal position, and the animal holds itself vertically, sometimes with the head upwards, but most frequently with it downwards. The faulty position of the air-bladder and the too slight development of the fins neutralize the influence of these directive agents; the want of equilibrium persists, the young animal can no longer seek its nourishment, and it dies in two or three days. I have scarcely been able to make them live for ten or twelve days by mixing triturated animal matter with the water of my aquaria. I have, however, no doubt that the rearing of the young fry which remain will furnish me with some new facts.-Comptes Rendus, November 4, 1872, tome lxxv. p. 1127.

\title{
Additional Observations on Codiophyllum.
}

By Dr. J. E. Gray, F.R.S. \&e.

More than one botanist has asked me for a specimen of Codiophyllum (described in the 'Annals,' for August 1872), which they wanted to examine microscopically and to unravel the fibre. The very expression shows that I have not sufficiently explained the structure of this very curious plant; but I believed that Mr. Ford's excellent figure would exhibit it better than I could explain it in words. The frond of this curious Alga is not formed of continuous fibres interlaced together, but of a number of oblong rings of a cylindrical tube, each gradually formed and all connected and anastomosed together, so as to form an expanded frond: each ring is separately formed; and when complete it sends from a part of its surface a tube of the same form, size, and structure, which gradually lengthens, after a time curves back, and unites itself to the ring from which it sprung, thus forming another ring, and in time emitting a new ring from its surface in the same manner.

Mr. Ford has attempted to show this development in his figure. 


\section{$2 \mathrm{BHL}$ Biodiversity Heritage Library}

Gray, John Edward. 1873. "Additional observations on Codiophyllum." The Annals and magazine of natural history; zoology, botany, and geology 11, 77-77. https://doi.org/10.1080/00222937308696765.

View This Item Online: https://www.biodiversitylibrary.org/item/81041

DOI: https://doi.org/10.1080/00222937308696765

Permalink: https://www.biodiversitylibrary.org/partpdf/62656

\section{Holding Institution}

Smithsonian Libraries

\section{Sponsored by}

Smithsonian

\section{Copyright \& Reuse}

Copyright Status: Public domain. The BHL considers that this work is no longer under copyright protection.

This document was created from content at the Biodiversity Heritage Library, the world's largest open access digital library for biodiversity literature and archives. Visit BHL at https://www.biodiversitylibrary.org. 